\title{
SISTEM INFORMASI PENILAIAN KINERJA PEGAWAI PADA KANTOR KECAMATAN SUKODADI DI KABUPATEN LAMONGAN DENGAN METODE AHP DAN BOOTSTRAP
}

\author{
Sundiya Eryfa Diana), M. Hasan Wahyudi²), M. Ghofar Rohman ${ }^{3)}$ \\ ${ }^{1)}$ Mahasiswa Program Studi Teknik Informatika, Fakultas Teknik, Universitas Islam Lamongan \\ ${ }^{2,3)}$ Dosen Program Studi Teknik Informatika, Fakultas Teknik, Universitas Islam Lamongan \\ E-mail: adianaeryfa24@gmail.com ${ }^{1}$,eldjava@yahoo.com ${ }^{2}$, m.ghofarrohman@unisla.ac.id ${ }^{3}$
}

\begin{abstract}
ABSTRAK
Selama ini, penilaian kinerja pegawai di Kantor Kecamatan Sukodadi Kabupaten Lamongan dilakukan oleh petugas penilai yang berkoordinasi dengan Kepala Kantor. Sebelumnya terlebih dahulu dilakukan penghitungan manual tanpa menggunakan suatu sistem. Perhitungan yang dilakukan berupa penentuan kelayakan pemenuhan syarat kenaikan pangkat pegawai. Sistem pendukung keputusan dapat membantu dalam menentukan penilaian atas hasil kerja pegawai untuk tujuan kenaikan pangkat reguler dengan menggunakan suatu metode. Adanya metode yang dapat digunakan dalam sistem pendukung keputusan diantaranya yaitu metode Analytical Hierarchi Process (AHP). Sistematis dan tepat dalam proses pengambilan keputusan yang mampu menunjukkan nilai kompetensi pegawai sesuai dengan kriteria yang ditetapkan oleh pihak Kantor atau pengambil keputusan berdasarkan analisa data yang sistematis untuk tujuan kenaikan pangkat reguler.
\end{abstract}

Kata kunci : Website, Bootstrap, Analytical Hierarchi Process (AHP)

\section{ABSTRACT}

So far, the employee performance assessment at the office of sukodadi sud district in lamongan regency is conducted by the appraisal officer in coordination with the Head Office. Previously was done manual calculation without using a system. The calculation carried out in the form of determination of eligibility fulfillment of promotion of employee. Decision support systems can assist in determining assessments of employee work for the purpose of regular promotion by using a method. The existence method can be used in decision support systems such as Analytical Hierarchi Process (AHP). Systematic and appropriate in the decision-making process that is able to show the value of the competence of employees in accordance with the criteria established by the Office or decision makers based on systematic data analysis for the purpose of promotion of regular.

Keywords : Website, Bootstrap, Analytical Hierarchi Process (AHP).

\section{PENDAHULUAN}

Pegawai merupakan sumber daya yang sangat penting untuk menentukan keberhasilan suatu satuan kerja. Pegawai yang berkualitas akan memudahkan satuan kerja dalam mencapai tujuannya, baik dalam hal pengabdian maupun pelayanan. Upaya meningkatkan kualitas kinerja seorang pegawai yaitu adanya kenaikan pangkat. Pangkat merupakan kedudukan yang menunjukkan tingkatan seseorang Pegawai berdasarkan jabatannya dalam rangkaian susunan kepegawaian dan digunakan sebagai dasar penggajian. Kenaikan pangkat adalah penghargaan yang diberikan atas prestasi kerja dan pengabdian Pegawai terhadap Negara, serta sebagai dorongan kepada Pegawai untuk lebih meningkatkan prestasi kerja dan pengabdiannya. Oleh karena hal tersebut perlu adanya penilaian dalam menentukan kenaikan pangkat.

Selama ini, penilaian kinerja pegawai di Kantor Kecamatan Sukodadi Kabupaten Lamongan dilakukan oleh petugas penilai yang berkoordinasi dengan Kepala Kantor. Sebelumnya terlebih dahulu dilakukan penghitungan manual tanpa menggunakan suatu 
sistem. Perhitungan yang dilakukan berupa penentuan kelayakan pemenuhan syarat kenaikan pangkat pegawai.

Sistem pendukung keputusan dapat membantu dalam menentukan penilaian atas hasil kerja pegawai untuk tujuan kenaikan pangkat reguler dengan menggunakan suatu metode. Adanya metode yang dapat digunakan dalam sistem pendukung keputusan diantaranya yaitu metode Analytical Hierarchi Process (AHP). Sistematis dan tepat dalam proses pengambilan keputusan yang mampu menunjukkan nilai kompetensi pegawai sesuai dengan kriteria yang ditetapkan oleh pihak Kantor.

Dengan adanya aplikasi ini diharapkan penilaian kinerja bertujuan untuk menilai seberapa baik karyawan telah melaksanakan pekerjaannya dan apa yang harus mereka lakukan untuk menjadi lebih baik di masa mendatang. Ini dilaksanakan dengan merujuk pada isi pekerjaan ayang mereka lakukan dan apa yang mereka harapkan untuk mencapai setiap aspek dari pekerjaan mereka.

Bagaimana rancang bangun Sistem Informasi Penilaian Kinerja Pegawai Pada Kantor Kecamatan Sukodadi di Kabupaten Lamongan dengan Metode AHP dan Bootstrap?

Untuk membangun sebuah sistem informasi penilaian kinerja pegawai pada kantor kecamatan sukodadi di kabupaten lamongan dengan metode AHP dan Bootstrap.

\section{Penilaian Kinerja}

Pada Tabel 1 adalah sumber Penilaian dari Kecamatan Sukodadi.

Tabel 1. Penilaian Kinerja

\begin{tabular}{|c|c|c|c|c|c|c|}
\hline \multicolumn{6}{|c|}{ UNSUR YANG DINILAI } & \multirow{2}{*}{$\begin{array}{c}\text { JUMLAH } \\
49.77\end{array}$} \\
\hline a. & \multicolumn{3}{|c|}{ SasaranKerja Pegawai (SKP) } & 82.95 & $\begin{array}{c}X \\
60 \%\end{array}$ & \\
\hline \multirow{9}{*}{ b. } & \multirow{9}{*}{$\begin{array}{l}\text { Perilaku } \\
\text { Kerja }\end{array}$} & 1. & Orientasi Pelayanan & 88.00 & (Baik) & \\
\hline & & 2. & Integritas & 86.00 & (Baik) & \\
\hline & & 3. & Komitmen & 87.00 & (Baik) & \\
\hline & & 4 & Disiplin & 90.00 & (Baik) & \\
\hline & & 5. & Kerjasama & 90.00 & (Baik) & \\
\hline & & & Kepemimpinan & 90.00 & (Baik) & \\
\hline & & & nlah & 531.00 & 0 & \\
\hline & & & ai Rata-rata & 88.50 & (Baik) & \\
\hline & & & ai Perilaku kerja & 88.50 & $\mathrm{X} \quad 40 \%$ & 35.40 \\
\hline \multirow{2}{*}{\multicolumn{6}{|c|}{ Nilai Prestasi Kerja }} & 85.17 \\
\hline & & & & & & (Baik) \\
\hline
\end{tabular}

AHP (Analytic Hierarchy Process) Adalah suatu teori umum tentang pengukuran yang digunakan untuk menemukan skala rasio, baik dari perbandingan berpasangan yang diskrit maupun kontinyu. AHP menguraikan masalah multi faktor atau multi kriteria yang kompleks menjadi suatu hirarki. Hirarki didefinisikan sebagai suatu representasi dari sebuah permasalahan yang kompleks dalam suatu struktur multi level dimana level pertama adalah tujuan, yang diikuti level faktor, kriteria, sub kriteria, dan seterusnya ke bawah hingga level terakhir dari alternatif. Dengan hirarki, suatu masalah yang kompleks dapat diuraikan ke dalam kelompok-kelompoknya yang kemudian diatur menjadi suatu bentuk hirarki sehingga permasalahan akan tampak lebih terstruktur dan sistematis[1].

Untuk mendapatkan suatu nilai tertentu dari semua nilai responden dilakukan perhitungan rata-rata geometrik, secara sistematis dapat dituliskan dalam persamaan berikut :

$$
g_{i j=\sqrt[m]{\Pi_{k=1}^{m} a i j}}
$$

Keterangan :

$\mathrm{g}_{\mathrm{ij}}$ :rata-rata geometrik pendapat gabungan

$\mathrm{a}_{\mathrm{ij}}$ :nilai skala perbandingan antara kriteria ke i dan ke j

$\mathrm{m}$ :jumlah responden

Langkah selanjutnya adalah menghitung konsistensi logis dimana Setelah semua matriks terbentuk dan semua perbandingan tiap pasangan elemen didapat, selanjutnya dapat dihitung matriks eigen (eigenvector) dan nilai eigen maksimum. Nilai eigen maksimum merupakan nilai parameter yang sangat penting dalam teori AHP. Nilai ini digunakan sebagai indeks acuan (reference index) untuk menyeleksi informasi melalui perhitungan rasio konsistensi (Consistensy Ratio (CR)) dari matriks estimasi dengan tujuan untuk memvalidasi apakah matriks perbandingan telah memadai dalam memberikan penilaian secara konsistensi atau belum.

Nilai CR dapat dihitung dengan urutan sebagai berikut :

1. Perkalian baris

$$
Z_{i j}=\sqrt[n]{\Pi_{j}^{n}=1_{i j}^{a}}
$$

Keterangan :

II : perkalian

$\mathrm{a}_{\mathrm{ij}}$ : nilai skala perbandingan antara kriteria ke 1 dan ke $\mathrm{j}$

2. Perhitungan vektor prioritas atau vektor eigen 


$$
V P=\frac{1}{\mathrm{~J} \text { total }}
$$

Keterangan :

$\mathrm{VP}=$ vektor prioritas

$\mathrm{J}=$ jumlah tiap variable

3. Perhitungan nilai eigen maksimum

$\lambda$ maks $=\sum$ (jumlah kolom ke j) $\mathrm{x}$

Vp untuk $\mathrm{i}=\mathrm{j}$ (4)

Keterangan :

$\lambda$ maks $=$ nilai eigen maksimum

a. Perhitungan Indeks

Konsistensi/Consistensy Index (CI)

Perhitungan ini dimaksudkan untuk mengetahui konsistensi jawaban yang akan berpengaruh kepada ketepatan hasil.

Rumusnya adalah sebagai berikut :

$\mathrm{CI}=\frac{\mathrm{nmaks}-\mathrm{n}}{\mathrm{n}-1}$

Keterangan :

$\lambda$ Maks : nilai eigen maksimum

$\mathrm{n} \quad$ : jumlah matrik perbandingan kriteria

b. Perhitungan Rasio

Konsistensi/Consistency Ratio (CR)

Mengetahui nilai CI cukup baik atau tidak, perlu diketahui rasio yang dianggap baik, yaitu $\mathrm{CR} \leq 0,1$. Jika nilai $\mathrm{CR}>0,1$ maka pertimbangan yang dibuat perlu diperbaiki dengan melakukan pengisisan ulang untuk menjawab pertanyaan dalam kuesioner. Rumusnya adalah sebagai berikut :

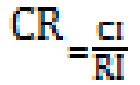

Keterangan :

CI : Consistency Index

RI : Random Index

MySQL merupakan perangkat lunak open source yang artinya perangkat lunak tersebut dapat digunakan dan dikembangkan oleh siapapun. Setiap orang dapat mengunduh aplikasi tersebut dari internet dan tanpa dikenakan biaya apapun.Dan jika kita mau kita bisa mempelajari source code dari MySQL dan memodifikasinya sesuai dengan kebutuhan kita [2].

PHP adalah bahasa pemrograman script yang paling banyak dipakai saat ini. PHP banyak dipakai untuk memrogram situs web dinamis, walaupun tidak tertutup kemungkinan digunakan untuk pemakaian lain.
Contoh terkenal dari aplikasi PHP adalah forum (phpBB) dan MediaWiki (software di belakang Wikipedia). PHP juga dapat dilihat sebagai pilihan lain dari ASP.NET/C\#/VB.NET Microsoft, ColdFusion Macromedia, JSP/Java Sun Microsystems, dan CGI/Perl. Contoh aplikasi lain yang lebih kompleks berupa CMS yang dibangun menggunakan PHP adalah Mambo, Joomla!, Postnuke, Xaraya, dan lainlain [3].

\section{METODOLOGI PENILITIAN}

Dalam penulisan skripsi ini, dilakukan pengumpulan data dengan menggunakan beberapa metode yaitu :

1. Studi Literatur

a. Pencarian sumber-sumber informasi dan literature guna mempelajari teori-teori penunjang yang berhubungan dengan Kantor Kecamatan Sukodadi .

b. Dilakukan dengan cara mengumpulkan dan mempelajari semua informasi yang berhubungan dengan Kantor Kecamatan Sukodadi yang akan dibuat.

2. Pengumpulan Data-data

Pengumpulan data dilakukan dengan pengamatan langsung di lapangan dengan menggunakan teknik :

a. Wawancara (Interview)

Metode dilakukan dalam rangka untuk mendapatkan data dan informasi yaitu dengan melakukan wawancara atau tanya jawab langsung dengan pihak Kantor Kecamatan Sukodadi Kabupaten Lamongan untuk mendapatkan data dan informasi yang dibutuhkan.

b. Observasi

Observasi atau melakukan pengamatan langsung di lokasi atau di lapangan agar mendapatkan informasi atau data yang sesuai fakta di lapangan dan yang dapat menunjang dalam pembuatan laporan nantinya.

3. Analisa dan Desain Sistem

Sistem Informasi Penilaian Kinerja Pegawai pada Kantor Kecamatan Sukodadi di Kabupaten Lamongan ini dilakukan dengan data yang sudah didapatkan dan dikembangkan dengan menggunakan AHP dan Bootstrap.

4. Pengujian

Melakukan uji coba pada program yang telah dibuat apakah sesuai dengan solusi 
yang diharapkan oleh Kantor Kecamatan Sukodadi.

5. Dokumentasi

Mendokumentasikan semua file dari program yang telah dibuat oleh penulis.

Kebutuhan fungsional dalam perancangan suatu sistem informasi diarahkan kepada pemanfaatan teknologi secara maksimal yang terdiri dari beberapa elemen atau komponen yang membentuk jaringan kerja dan mempunyai tujuan yang ingin dicapai. Suatu sistem dapat terdiri dari sistem bagian subsistems. Sebagai misal, sistem komputer dapat terdiri dari subsistem yang lebih kecil lagi atau terdiri dari komponen-komponen.

Kebutuhan non fungsional sistem yang dibangun pada Sistem Informasi Penilaian Kinerja Pegawai pada Kantor Kecamatan Sukodadi di Kabupaten Lamongan merupakan sistem atau aplikasi untuk memberikan nilai terhadap pegawai oleh atasan, setelah pegawai melakukan pekerjaan yang telah diberikan dengan batas waktu yang telah ditetapkan. Secara umum aplikasi yang akan dibangun pada penelitian ini adalah aplikasi sistem informasi yang bersifat website dengan menggunakan metode Analytic Hierarchy Process (AHP).

Kebutuhan perangkat keras (Hardware) yang dibutuhkan pada saat pembuatan aplikasi dan pada saat program diimplementasikan di objek penelitian antara lain:

1. CPU Dengan spesifikasi sebagai berikut :

a. Procesor minimal Core i3

b. RAM minimal $2048 \mathrm{Mb}$

2. Monitor

3. Mouse dan Keyboard

Kebutuhan perangkat lunak (software) adalah program yang berisi perintah-perintah untuk melakukan pengolahan data. Sistem Informasi Penilaian Kinerja Pegawai pada Kantor Kecamatan Sukodadi di Kabupaten Lamongan ini dibuat dengan menggunakan bantuan beberapa software, yang terdiri dari :

1. Sistem Operasi ( Windows 7/8/10)

2. Notepad ++

3. Adobe Photoshop

4. Xampp

Perancangan alur data merupakan gambaran dari program, bagaimana program itu akan berjalan sesuai dengan yang diharapkan. Hal ini akan diuraikan sebagai berikut :

Conceptual Data Model (CDM) pada prinsipnya sama dengan pemodelan pada relational model, dimana pendekatam data yang disajikan menggunakan Conceptual Data Model (CDM). Pada level ini data disajikan secara general dan spesifik terhadap suatu database.

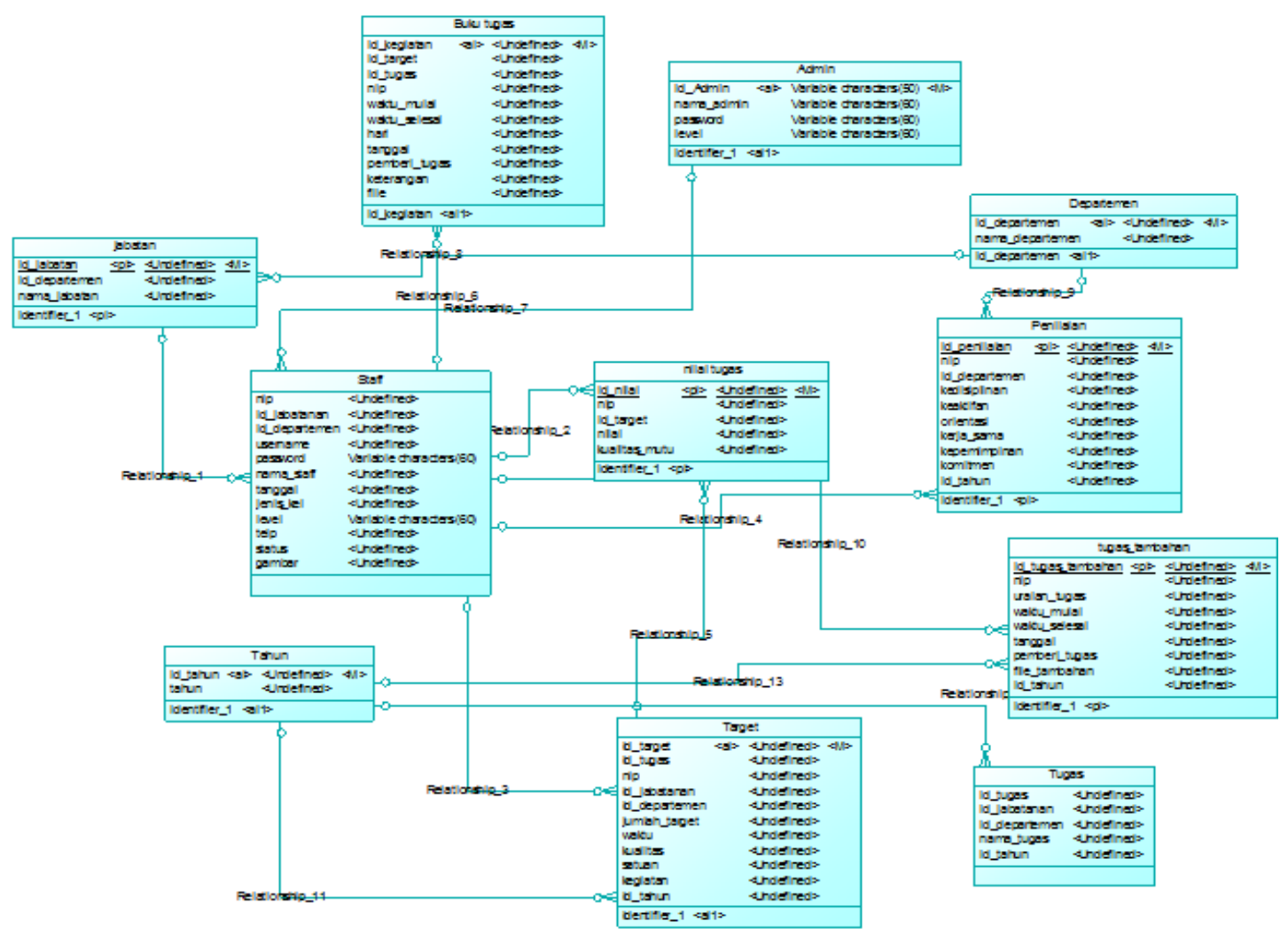

Gambar 1. Conceptual Data Model 
Physical Data Model (PDM) merupakan model fisik yang spesifik berdasarkan gambaran database yang diinginkan. PDM merupakan hasil generate Conceptual Data Model yang telah ada. Dengan level PDM, dapat di generate kembali kedalam sebuah bahasa definisi data Data Definition Languge
(DDL) atau menghubungkan kedalam library database melalui ODBC (Object Database Conectivity), yaitu melalui data source yang harus diatur terlebih dahulu. Dengan kedua langkah tersebut objek-objek atau tabel-tabel database dapat dibuat atau di generate dengan mudah

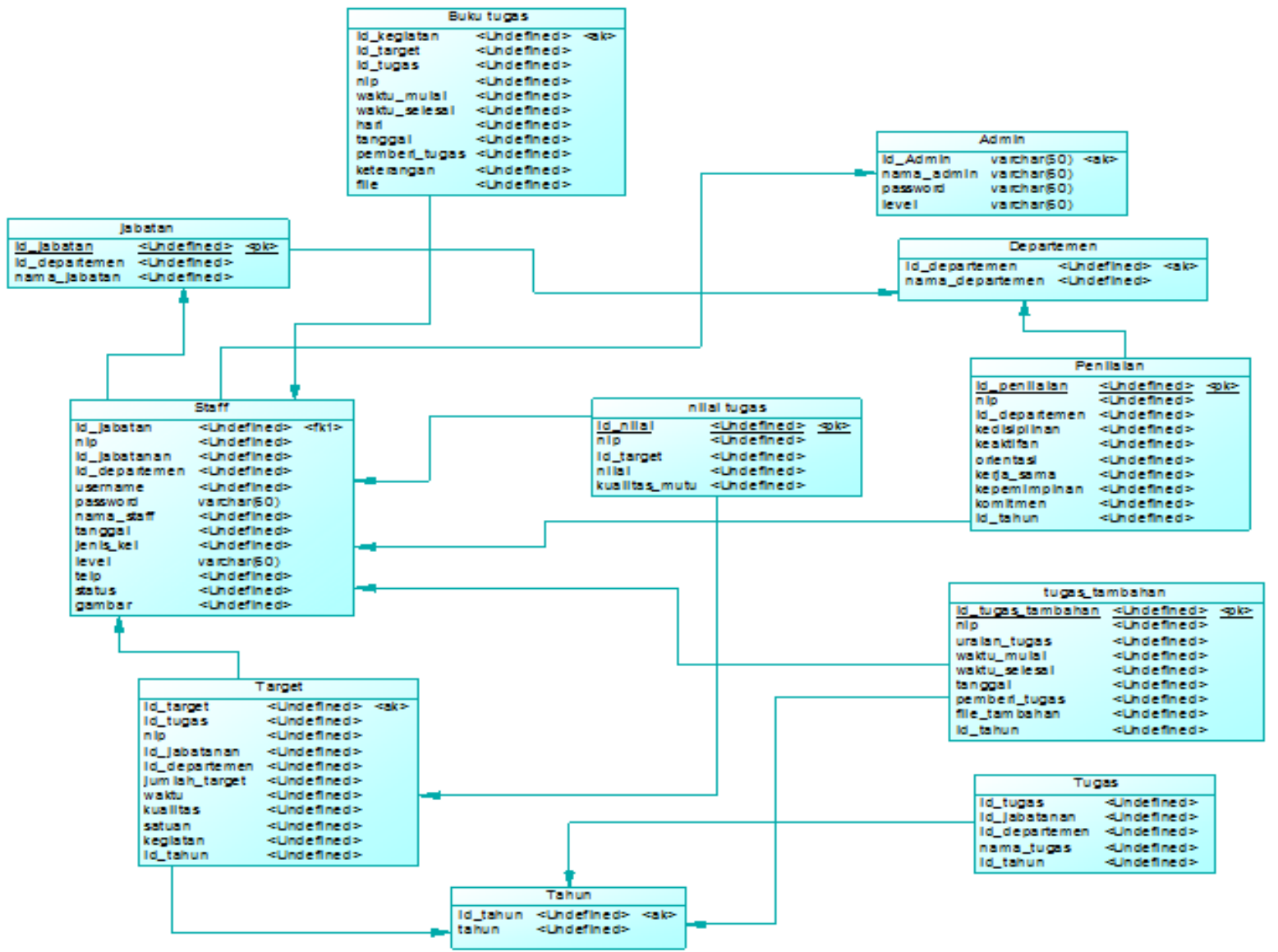

Gambar 2 Physical Data Model

Data Flow Diagram (DFD) adalah representasi grafik dari sebuah sistem. DFD menggambarkan komponen-komponen, sebuah sistem, aliran-aliran data dimana komponenkomponen tersebut, dan asal, tujuan, serta penyimpanan dari data tersebut. DFD dapat digunakan untuk dua hal utama, yaitu untuk membuat dokumentasi dari sistem informasi yang ada atau untuk menyusun dokumentasi untuk sistem informasi yang baru.

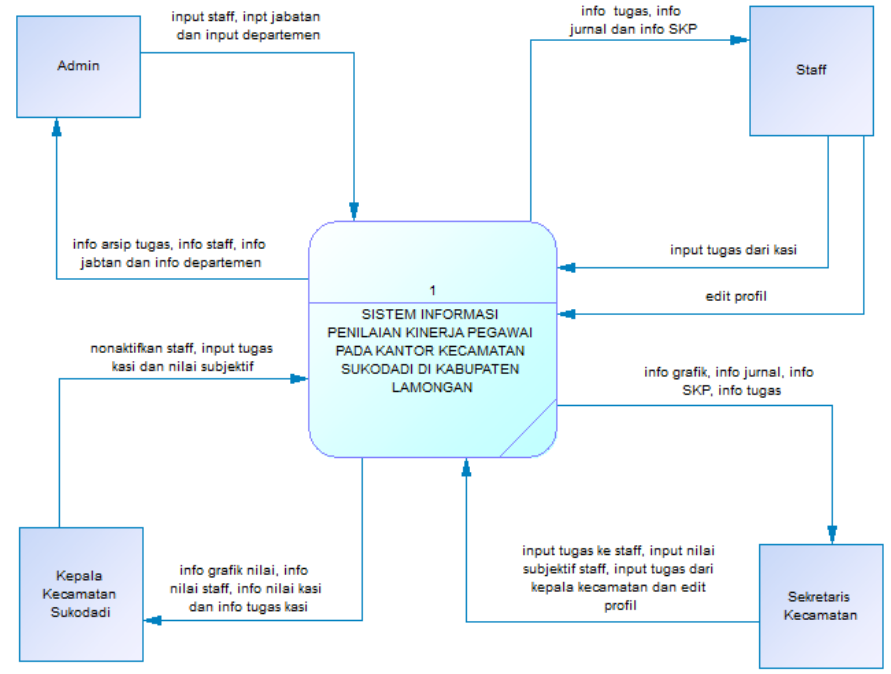

Gambar 3. Diagram Context 
Keterangan gambar 3:

Diagarm Context ini adalah gambaran umum dari sistem Aplikasi kinerja. Sistem ini memiliki 4 entity yaitu Admin, Staff, Staff Penilai, Kepala Kantor. Keempat Entity tersebut berpengaruh pada keberhasilan sistem ini penjelasan pengaruh entity pada sistem ini adalah sebagai berikut:

1. Admin atau Ahli adalah pihak yang bertugas melakukan input Staff Baru, input Jabatan dan input Departeman.
2. Staff adalah pihak yang bertugas melakukan pengerjaan tugas yang telah di targetkan oleh Staff Penilai.

3. Staff Penilai adalah pihak yang bertugas dalam pemberian tugas dan penilaian kepada staff serta melakukan pengerjaan tugas yang telah ditargetkan atau diberikan oleh kepala kantor.

4. Kepala kantor adalah pihak yang bertugas dalam pemberian tugas dan penilaian kepada staff penilai serta dapat menonaktifkan semua pegawai.

Data Flow Diagram Level 1 Cek Proses Login

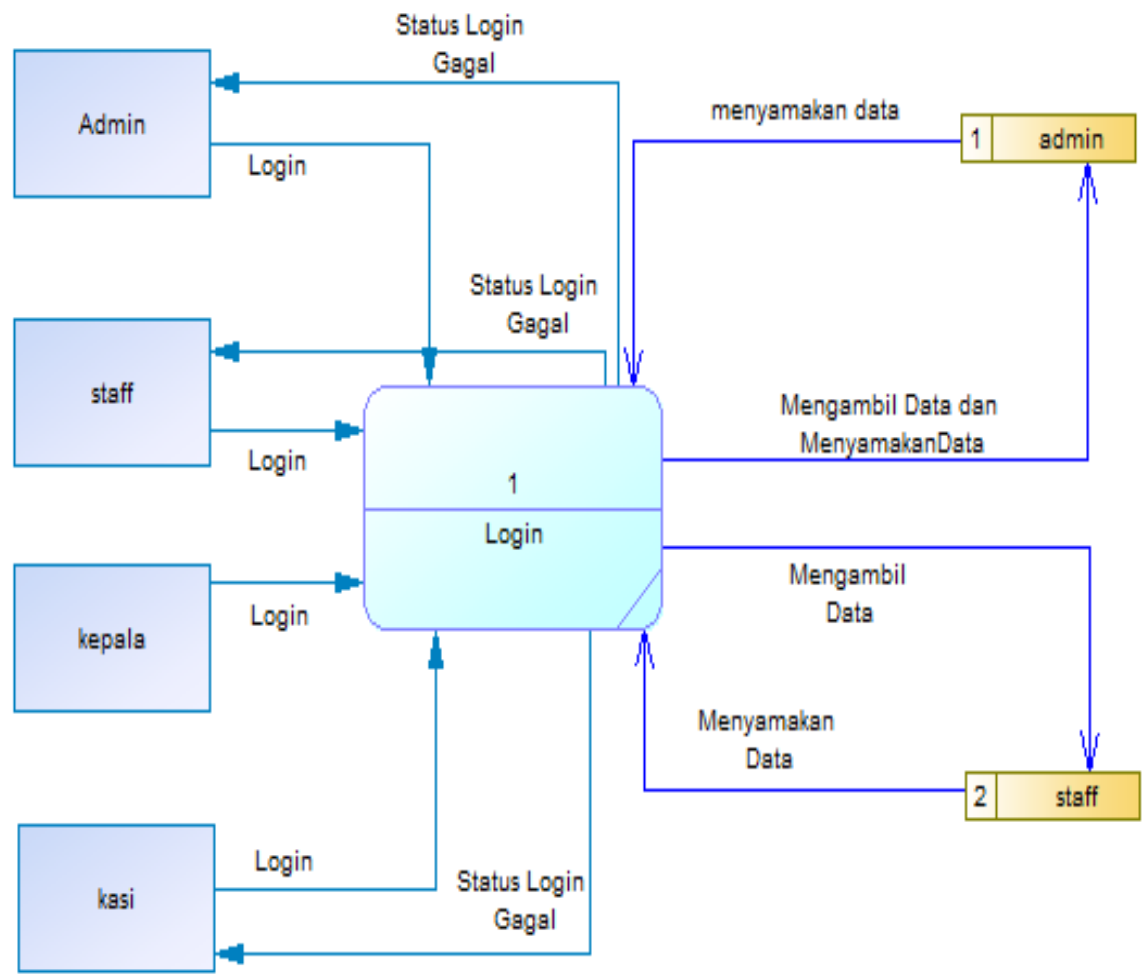

Gambar 4. DFD Level 1 Cek Proses Login

Keterangan gambar 4:

1. Pada DFD level 1 Proses Login, proses pertama adalah Admin melakukan login kemudian data diproses jika data yang dimasukan sama dengan data yang ada maka proses akan memberikan informasi berhasil atau tidak berhasilnya login tersebut kepada admin.
2. Pada DFD level 1 Proses Login, proses kedua adalah Staff, Kasi, Kepala melakukan login kemudian data diproses jika data yang dimasukan sama dengan data yang ada maka proses akan memberikan informasi berhasil atau tidaknya login tersebut kepada staff, kasi dan kepala. 
J u r n a l T e k n i k A

$\begin{array}{llllllllllll}\text { Vol } & 9 & \text { Nol } & 2 & \text { S e p t e m b e r } & 2 & 0 & 117,937-947\end{array}$

3. Data Flow Diagram Level 2 Cek Proses Maintenance Master

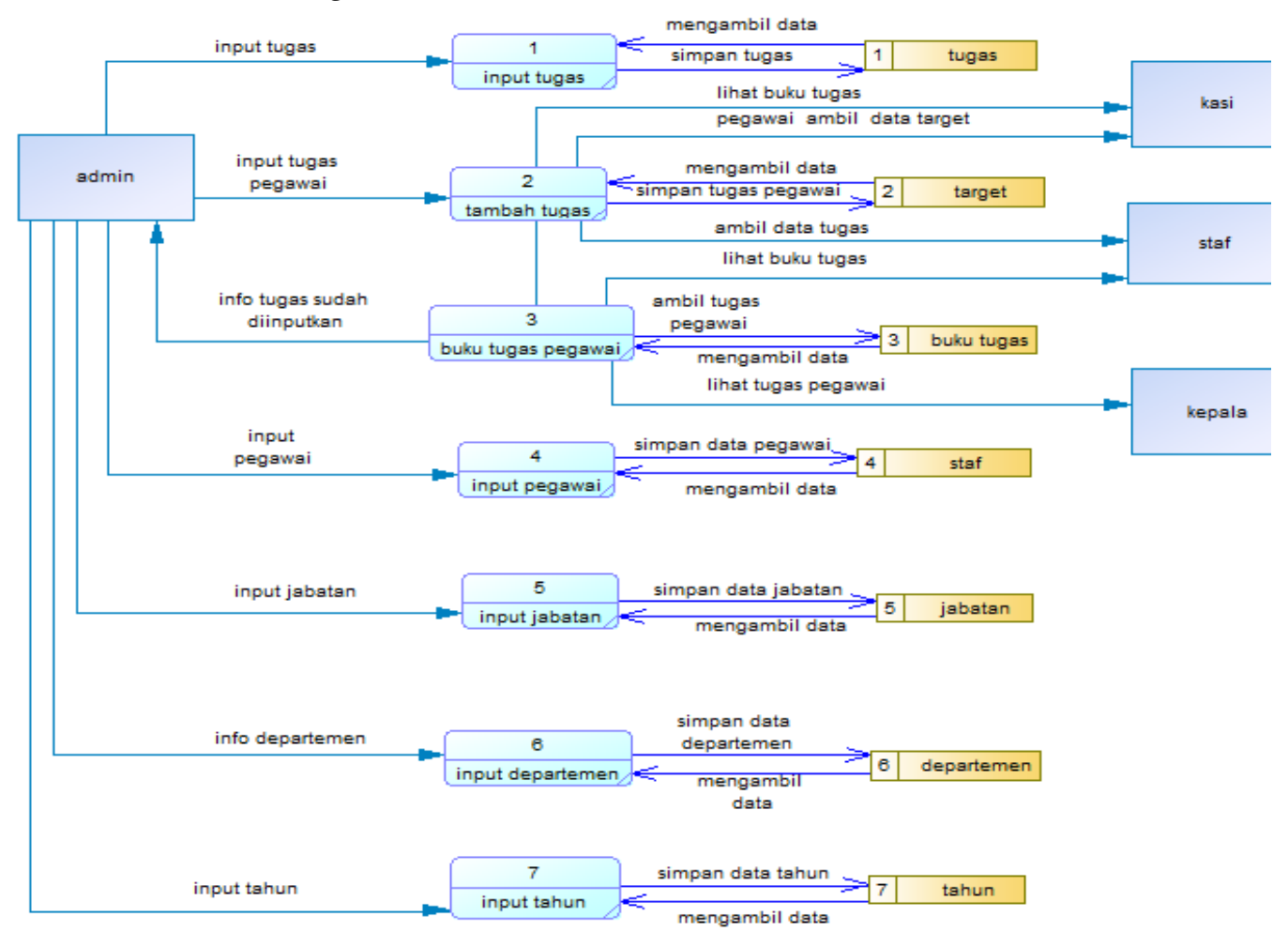

\section{Gambar 5. DFD Level 2 Cek Proses Maintenance Master}

Keterangan gambar 5:

1. Pada DFD level 2 Proses Maintence Master, ini merupakan proses admin untuk melakukan input tugas, tambah tugas, buku tugas pegawai, input pegawai, input jabatan, input departemen dan input tahun.
2. Kasi dan staf mengambil data tugas yang akan dikerjakan dan lihat buku tugas yang sudah dikerjakan.

3. Kepala lihat tugas kasi yang sudah dierjakan dan diinputkan di program ini.

Data Flow Diagram Level 3 Cek Proses Pemberian Tugas

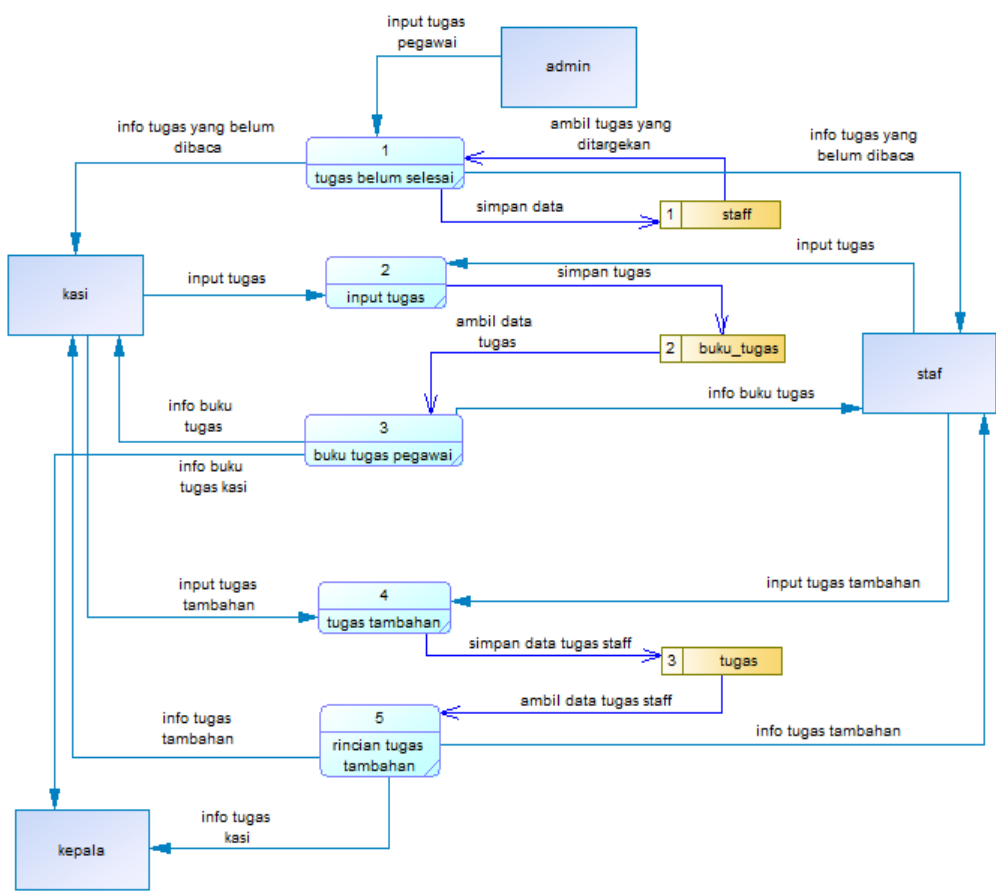

Gambar 6 DFD Level 3 Cek Proses Pemberian Tugas 
Keterangan gambar 6:

Pada DFD level 1 Proses Maintence Master ada tiga proses diantaranya :

1. Kasi mendapatkan info tugas yang sudah diinputkan oleh admin, setelah tugas yang sudah dikerjakan kasi menginputkan tugas tersebut, kasi bisa melihat tugas-tugas yang sudah dikerjakan, kasi juga bisa menginputkan tugas tambahan dan kasi bisa melihat informasi dari tugas tambahan yang sudah diinputkan.
2. Kepala dapat melihat buku tugas yang sudah dikerjakan oleh kasi dan dapat melihat informasi tugas tambahan kasi yang sudah diinputkan.

3. Staf mendapatkan info tugas yang sudah diinputkan oleh admin, setelah tugas yang sudah dikerjakan kasi menginputkan tugas tersebut, kasi bisa melihat tugas-tugas yang sudah dikerjakan, kasi juga bisa menginputkan tugas tambahan dan kasi bisa melihat informasi dari tugas tambahan yang sudah diinputkan.

Data Flow Diagram Level 4 Cek Proses Penilaian

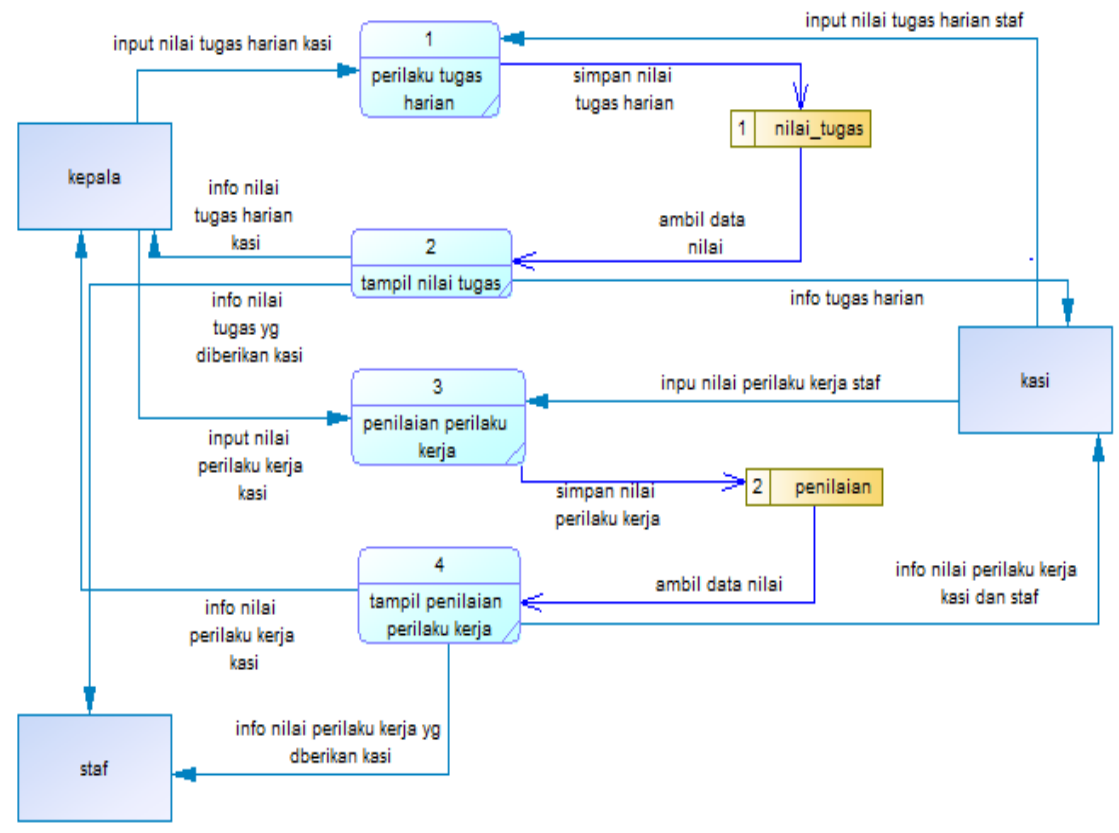

Gambar 7. DFD Level 4 Cek Proses Penilaian

Keterangan gambar 7:

Pada DFD level 1 Proses penilaian

1. Kepala melakukan input nilai tugas harian yang sudah dikerjakan oleh kasi, kepala bisa melihat info nilai tugas harian kasi, kepala melakukan input perilaku kerja kasi nilai ini diberikan setahun sekali dan kepala bisa mendapatkan info nilai perilaku kerja kasi.

2. Staf yang dapat info nilai tugas harian yang diberikan oleh kasi dan dapat informasi nilai prilaku kerja yang diberikan kasi.

3. Kasi melakukan input nilai tugas harian yang sudah dikerjakan oleh staf, kepala bisa melihat info nilai tugas harian staf, kasi melakukan input perilaku kerja staf nilai ini diberikan setahun sekali dan kasi bisa mendapatkan info nilai perilaku kerja staf.

Rancangan desain interface menguraikan perangan form-form yang ada dalam aplikasi. Meliputi perancangan form untuk pengguna umum dan pengguna administrator (jika terdapat beberapa tingkatan pengguna dalam aplikassi yang dirancang). Desain antarmuka berupa tampilan visual yang diberi penjelasan tiap-tiap bagiannya.

Apabila tugas terselesaikan masing-masing staff dapat menyetak hasil kerjanya berupa jurnal harian yang di cetak setiap hari dan berupa SKP (Sasaran Kerja Pegawai) yang di cetak Pertahun. Berikut Rancangan Desain Interface:

Rancangan Form Login 


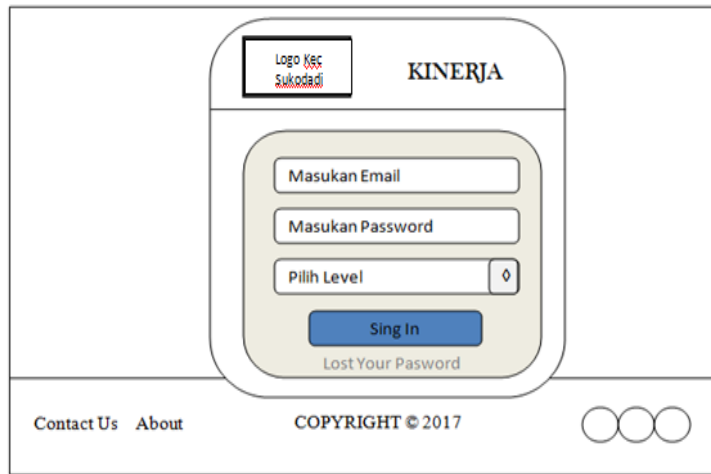

Gambar 8. Rancangan Form Login

Pada gambar 8 Ini adalah tampilan rancangan menu login yang di buat dalam aplikasi sebagi sistem keamanan agar tidak dapat di akses oleh orang lain kecuali admin, staff, staff penilai, dan kepala kantor.

Rancangan Form Menu Admin

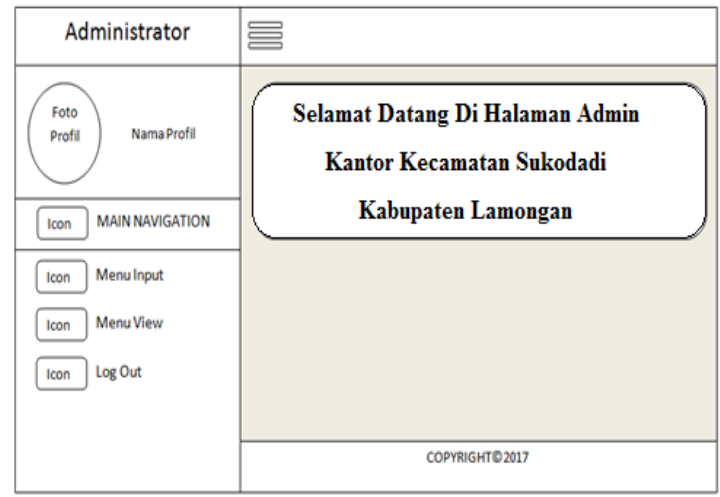

\section{Gambar 9. Rancangan Form Menu Admin}

Pada Gambar 9 menjelaskan tampilan awal desain menu utama admin dalam rancangan aplikasi penilaian kinerja pegawai Kantor Kecamatan Sukodadi berbasis websaite antara lain :

Menu Utama terdapat pilihan

1. Menu Input

Menu Input adalah menu yang menampilakan beberapa menu lain untuk melakukan input data, didalam menu input terdiri dari beberapa sub menu antara lain :

a. Input Pegawai

Adalah menu untuk mengintputkan data pegawai baru.

b. Input Jabatan

Adalah menu untuk mengintputkan data jabatan baru.

c. Input Departeman

Adalah menu untuk mengintputkan data departeman baru.

d. Input Tahun

Adalah menu untuk mengintputkan data tahun baru.
2. Menu View

Menu View adalah menu yang menampilakan beberapa menu lain untuk melakukan melihat data dan edit data, didalam menu view terdiri dari beberapa sub menu antara lain :

a. Lihat List Pegawai

Adalah menu untuk meliaht dan edit list data pegawai baru.

b. Lihat List Jabatan

Adalah menu untuk meliaht dan edit list data jabatan baru.

c. Lihat List Departeman

Adalah menu untuk meliaht dan edit list data departeman baru.

d. Lihat List Tahun

Adalah menu untuk meliaht dan edit list data tahun baru.

\section{Log Out}

Menu untuk keluar dari halaman admin menuju halaman utama.

\section{PEMBAHASAN}

Implementasi sistem ini menguraikan tentang implementasi sistem secara detail sesuai dengan rancangan dan berdasarkan komponen, tools dan bahasa pemrograman yang dipakai. Sistem informasi penilaian kinerja pegawai pada kantor Kecamatan Sukodadi di Kabupaten Lamongan dengan Metode Ahp dan Bootstrap ini terdiri dari beberapa tampilan di antaranya sebagai berikut :

Implementasi menu login adalah tampilan menu utama saat web dijalankan, untuk menjalankan login, admin harus mengisi kolom username dan password secara benar. Sebagai berikut gambar 10 :

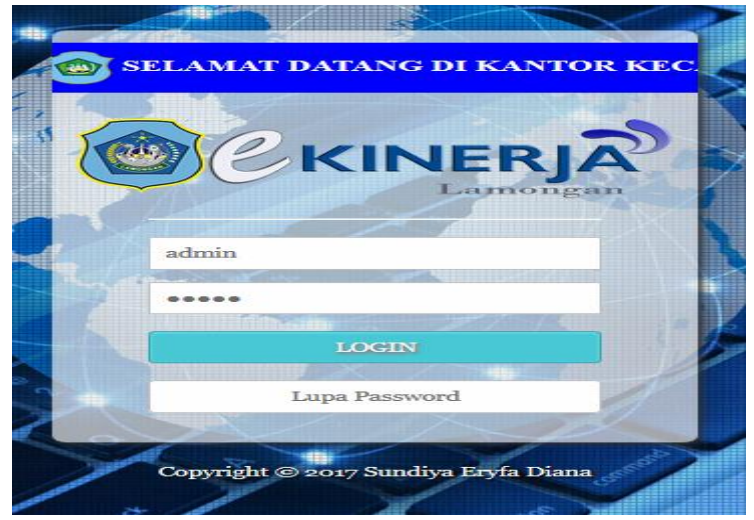

Gambar 10. Menu Login

Halaman ini sebagai tampilan awal halaman setelah proses login berhasil oleh admin. Berikut gambar 11 implementasi menu utama. 


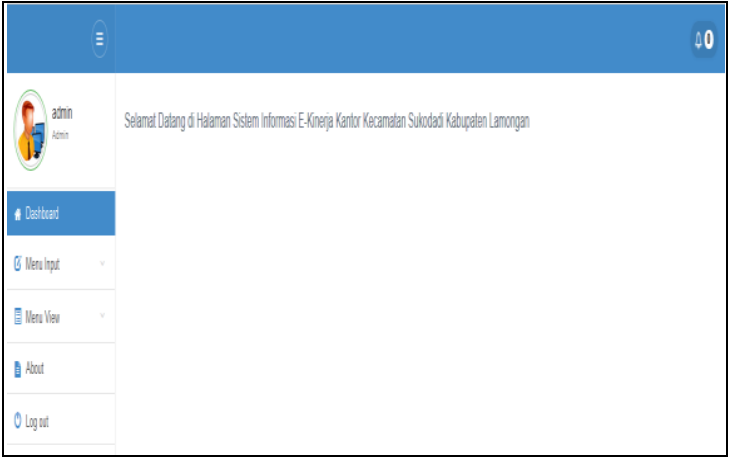

Gambar 11. Menu Utama

Gambar 12 ini merupakan tampilan hasil dari perhitungan mulai yang dikerjakan seperti berikut: nilai tugas setiap hari dan nilai criteria 1 tahun sekali. Berikut gambar 12 .

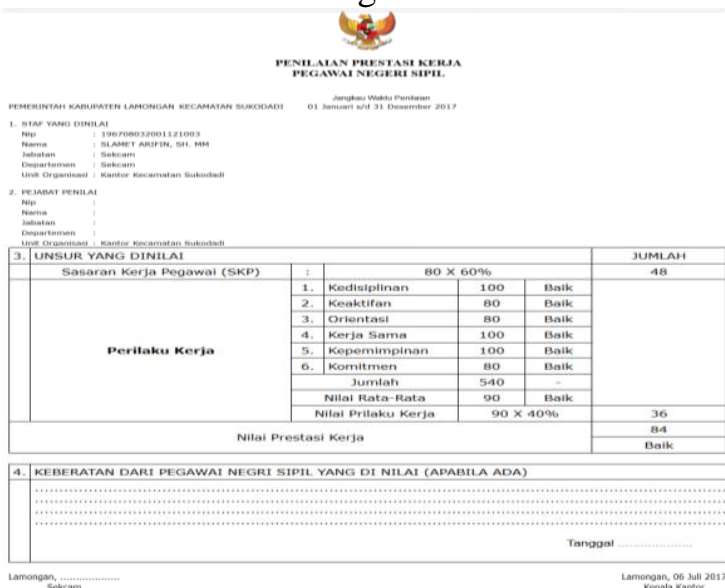

\section{Gambar 12. Pengujian Menu Penilaian Prestasi Kerja}

Gambar 13 merupakan penilaian SKP yang secara manual yang dilakukan oleh penulis menggunakan software excel.

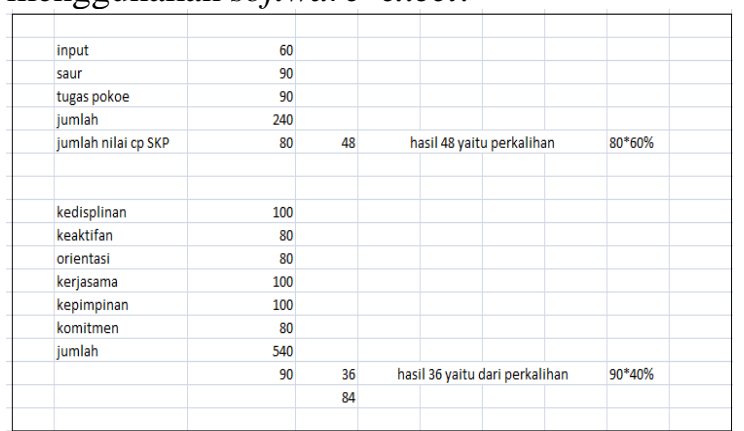

\section{Gambar 13. Percobaan Penilaian SKP} Secara Manual

Dalam pembahasan hasil penelitian ini, untuk program sistem pendukung keputusan dalam sistem informasi penilaian kinerja pegawai dengan metode AHP ini telah diuji coba kepada beberapa pegawai dengan kriteriakiteria data yang berbeda antara satu dengan yang lain, dengan tujuan apakah aplikasi sistem pendukung keputusan ini kenaikan jabatan sudah bisa menentukan tahap penilaian pegawai untuk proses kenaikan jabatan. Untuk mengecek kebenaran dari sistem ini, peneliti membandingkan perhitungan program dan perhitungan manual (excel) supaya hasil nilai yang ingin dicapai sesuai dengan yang diinginkan. Karena nilai total ini yang dijadikan dasar sebagai nilai prioritas pegawai yang sesuai dari contoh yang diberikan oleh pihak kantor, untuk mempermudah dan mempercepat proses penilaian kinerja ini maka dibuat program dengan metode AHP.

Prosentase tingkat kevalidasian dari uji program yang telah dilakukan di Kantor Kecamatan Sukodadi Kabupaten Lamongan. Hal ini didapatkan berdasarkan uji program Sistem Pendukung Keputusan kenaikan jabatan dengan Metode AHP yang disesuaikan dengan uji penilaian yang dilakukan oleh Kantor Kecamatan Sukodadi Kabupaten Lamongan.

\section{KESIMPULAN}

Kesimpulan yang dapat diambil dari Aplikasi Sistem Informasi Geografis Lokasi Bengkel di Kabupaten Lamongan Berbasis Android ini antara lain : Dari pembahasan sebelumnya dapat diambil kesimpulan dengan menggunakan sistem informasi penilaian kinerja pegawai pada kantor kecamatan sukodadi di kabupaten lamongan dengan metode ahp dan bootstrap ini, dalam penggunaan sistem ini terdapat beberapa keuntungan dan didapatkan hasil yang akurat. Hasil yang diinginkan juga dapat dilihat setiap waktu dengan cepat kapanpun dibutuhkan dan penyimpanan data terjamin, aman serta tidak memakan media penyimpanan yang terlalu besar sehingga menghasilkan sistem yang terkoputerisasi sangat efektif dan efisien jika dibandingkan dengan sistem manual yang digunakan selama ini.

Hasil percobaan yang diperoleh dari uji program yang disesuaikan dengan input an data yang ada berdasarkan data yang didapat dari kecamatan sukodadi. Data yang ditampilkan berupa data sistem penilaian kinerja menggunakan website yang memudahkan pegawai kantor kecamatan dalam proses pekerjaan. 
DAFTAR PUSTAKA

[1] Eko, Darmanto, dkk 2014 "Penerapan Metode Ahp (Analythic Hierarchy Process) UntukMenentukan Kualitas Gula Tumbu", Fakultas Teknik, Program Studi Sistem Informasi. (di akses pada tanggal 2 Mei 2017).

[2] Ariyanti, Rena. dkk 2015. "Pemanfaatan Google Maps Api Pada Sistem Informasi Geografis Direktori Perguruan Tinggi Di Kota Bengkulu", Fakultas Ilmu Komputer Universitas Dehasen Bengkulu.
[3] Ramadhani, Syaifudin. dkk 2013. "Rancang Bangun Sistem Informasi Geografis Layanan Kesehatan Di Kecamatan Lamongan Dengan PHP MySQL" Fakultas Teknik Informatika Universitas Islam Lamongan. 
Jurna l T e knikA

$\begin{array}{lllllllll}\text { V o l } & 9 & \text { N o } 2 & \text { S e p t e m b e r } & 2 & 0 & 17,937-947\end{array}$

ISSN No. 2085 - 0859

Halaman ini sengaja dikosongkan 